CLINICAL STUDY

\title{
Density of ghrelin-producing cells is higher in the gastric mucosa of morbidly obese patients
}

\author{
Fabiana A N Maksud ${ }^{1,3}$, Jairo S Alves ${ }^{2}$, Marco T C Diniz ${ }^{2}$ and Alfredo J A Barbosa ${ }^{1,2}$ \\ ${ }^{1}$ Laboratory of Digestive and Neuroendocrine Pathology, ${ }^{2}$ Alfa Institute of Gastroenterology, Faculty of Medicine, Federal University of Minas Gerais \\ (UFMG), Avenida Alfredo Balena 190, 30130-100 Belo Horizonte, Brazil, and ${ }^{3}$ Federal University of Ouro Preto, Ouro Preto, Brazil
}

(Correspondence should be addressed to A J A Barbosa at Laboratory of Digestive and Neuroendocrine Pathology; Email: abarbosa@medicina.ufmg.br)

\begin{abstract}
Background: Ghrelin is a peptide mainly secreted by gastric mucosa and has been implicated in the regulation of eating behavior and weight balance. Obesity and Helicobacter pylori infection are associated with changes in plasma ghrelin levels.

Objective: This study was designed to evaluate the density of ghrelin-producing cells in the gastric mucosa of morbidly obese and dyspeptic non-obese patients, with and without H. pylori infection.

Methods: Gastric biopsies of the antral and oxyntic mucosa were obtained from 50 morbidly obese patients (BMI > 40, 21 with metabolic syndrome (MS)), 17 dyspeptic overweight subjects $(25<\mathrm{BMI}<30)$, and 33 lean individuals $(\mathrm{BMI}<25)$ and processed for histology and immunohistochemistry.

Results: Ghrelin-immunoreactive cell densities in the oxyntic mucosa were similar in morbidly obese patients with MS and in overweight and lean patients, whereas morbidly obese patients without MS presented higher ghrelin-immunoreactive cell density. The number of ghrelin cells in the oxyntic mucosa was significantly lower in obese and non-obese H. pylori-infected subjects. Ghrelin-immunoreactive cells, although sparse in the antral mucosa, were found more frequently in obese patients and their numbers did not seem to be affected by H. pylori infection.

Conclusions: The higher expression of ghrelin-immunoreactive cells in the oxyntic mucosa of morbidly obese patients compared with non-obese subjects or with morbidly obese subjects with MS and the finding of a higher number of small foci of ghrelin cells in the antral mucosa of obese patients may indicate an adaptive mechanism or an individual factor to be considered in the pathogenesis of obesity.
\end{abstract}

European Journal of Endocrinology 165 57-62

\section{Introduction}

Obesity, a condition that presents an increasing prevalence worldwide, has become an alarming public health problem and is frequently associated with several pathological conditions such as diabetes mellitus, hypertension, coronary heart disease, and cancer, among others. The factors that affect the evolution of obesity are not well known, although it is believed that its pathogenesis may be multifactorial.

A number of gastrointestinal peptides have been reported as possible elements that could interfere with the disruption of the homeostasis between food intake and energy expenditure. Among the gastrointestinal hormones, the 28 amino acid peptide ghrelin appears to play a role in long-term appetite regulation and in the control of energy homeostasis. This peptide was discovered as the endogenous ligand of the $\mathrm{GH}$ secretagogue receptor, and soon afterward, it was observed that a gradient of ghrelin production occurs along the gastrointestinal tract, with highest expression in the oxyntic gastric mucosa (1-3).

As gastric mucosa is a frequent site of chronic and persistent lesions, the gastric production of ghrelin may be affected along the evolution of these conditions, such as infection with Helicobacter pylori (4). The number of gastrin- and somatostatin-producing cells of the gastric mucosa has been reported to be affected in $H$. pyloripositive duodenal ulcer patients $(5,6)$. In addition, it has been reported that $H$. pylori infection seems to be associated with a significant decrease in plasma ghrelin levels that return to normal levels after eradication of this microorganism (7-10). In contrast, no difference in plasma ghrelin levels between $H$. pylori-positive and H. pylori-negative subjects matched for body mass index (BMI) has been shown by others $(11,12)$, leading to controversy about this subject. Furthermore, H. pylori infection may have a negative effect on the density of gastric ghrelin-immunoreactive cells. Impaired production of gastric ghrelin has been shown in parallel 
to a decreased number of ghrelin-immunoreactive cells in the oxyntic mucosa of lean patients with chronic $H$. pylori-associated gastritis (7). These findings were also observed in obese patients infected with these microorganisms (13).

Recent reports suggest that hyperinsulinemia may interfere with serum ghrelin levels and also that ghrelin may modulate insulin secretion and contribute to obesity-associated insulin resistance in metabolic syndrome (MS) (14-18). On the other hand, obesity itself may interfere in some way with ghrelin production and release (19-22). Obese patients with Prader-Willi syndrome present increased plasma ghrelin concentrations and also an increased density of ghrelinimmunoreactive cells in the gastric mucosa (23-26). It should be mentioned that no comparative studies with a significant number of subjects are available regarding the density of ghrelin-immunoreactive cells in individuals with different BMI. This study was designed to evaluate the number of ghrelin-immunoreactive cells in the oxyntic and antral gastric mucosa of morbidly obese, overweight, and lean patients and its relationship to infection with $H$. pylori.

\section{Materials and methods}

\section{Subjects}

In this study, three groups of patients were studied: i) 50 obese patients ( 38 women, 12 men, mean age 35.4 years, BMI > 40) candidates for bariatric surgery. Among these obese patients, 21 (42\%) had MS according to the International Diabetes Federation (IDF) and National Cholesterol Education Program (NCEP) criteria, i.e. all these patients had dyslipidemia (triglycerides $\geq 150 \mathrm{mg} / \mathrm{dl}$ or reduced high-density lipoprotein cholesterol), hypertension (systolic BP $\geq 130 \mathrm{mmHg}$ or diastolic $\mathrm{BP} \geq 85 \mathrm{mmHg}$ ), and type 2 diabetes mellitus or hyperglycemia (fasting plasma glucose $\geq 100 \mathrm{mg} / \mathrm{dl}$ ) in addition to a high waist circumference $(27,28)$; ii) 17 overweight dyspeptic patients (14 women, three men, mean age 47.8 years, $25<\mathrm{BMI}<30$ ); and iii) 33 lean dyspeptic patients (18 women, 15 men, mean age 41.7 years, BMI $<25$ ) subjected to upper digestive endoscopy due to dyspeptic complaints and taking no medications. All patients were retrospectively and consecutively selected at the same general hospital Gastroenterology Unit. Patients with peptic ulcer or neoplastic lesions and patients presenting atrophic body gastritis at histology that could be suspected to be of autoimmune etiology were excluded. The clinical data of all patients were obtained from the hospital medical records. The Institutional ethics committee of the Federal University of Minas Gerais approved the study protocol, and written informed consent was obtained from all participants.

\section{Tissue specimens, histology, and immunohistochemistry}

A total of six tissue specimens of endoscopic gastric biopsies were obtained by the same endoscopist (J S A): four from the oxyntic mucosa (greater curvature, proximal smaller curvature, posterior and anterior walls) and two from the antral mucosa. The biopsy specimens were fixed in $4 \%$ formaldehyde and embedded in paraffin, and $4 \mu \mathrm{m}$ thick sections from each specimen were stained with hematoxylin and eosin for histology and with Giemsa for histological evaluation of $H$. pylori infection and immunohistochemistry. The biopsy specimens were examined in a blind manner by a pathologist and scored to indicate absent, mild, moderate, and severe inflammatory infiltrates, atrophy, and intestinal metaplasia according to the updated Sydney system (29). Ghrelin immunoreactivity was determined on sections after microwave pretreatment $(10 \mathrm{~min}$ in $0.01 \mathrm{M}$ citric acid solution) and overnight incubation at $4{ }^{\circ} \mathrm{C}$ with human polyclonal antibody (Phoenix Pharmaceutics, Inc., Burlingame, CA, USA) diluted 1:1000. Diaminobenzidine-hydrogen peroxide was used as chromogen, and the sections were counterstained with diluted hematoxylin.

\section{Evaluation of ghrelin cell density}

Ghrelin-immunoreactive cell density was evaluated on acquired microscopic digital images (Axiocam camera and KS 300 digital system, Zeiss, Germany) in six consecutive $0.21 \mathrm{~mm}$ wide columns containing the full mucosa thickness at $\times 400$ magnification. The results are expressed as the average number of cells $/ \mathrm{mm}^{2}$.

\section{Statistical analysis}

Statistical analysis was carried out using Epi-info version 6.04 and GraphPad Prism version 5.01 software (GraphPad Software Inc., La Jolla, CA, USA).

Table 1 Clinical and histological features of patients studied. Values are presented as $n(\%)$.

\begin{tabular}{lccc}
\hline & $\begin{array}{c}\text { Obese } \\
(\mathrm{BMI}>40)\end{array}$ & $\begin{array}{c}\text { Overweight } \\
(\mathrm{BMI} 25-30)\end{array}$ & $\begin{array}{c}\text { Lean } \\
(\mathrm{BMI}<25)\end{array}$ \\
\hline $\begin{array}{l}\text { Normal mucosa } \\
\text { Gastritis* }\end{array}$ & $19(38)$ & $4(23.5)$ & $5(15.2)$ \\
Without atrophy $_{\text {Atrophy }}$ & $27(54)$ & $12(70.6)$ & $20(60.6)$ \\
$H$. pylori-positive $_{\text {Metabolic syndrome }}{ }^{\mathrm{a}}$ & $25(50)$ & $1(5.8)$ & $7(21.2)$ \\
Total & $21(41)$ & $0(47)$ & $22(66.6)$ \\
Mean age (years) & 50 & 17 & $0(0)$ \\
\hline
\end{tabular}

${ }^{*} P=0.36$.

${ }^{a}$ Triglycerides $\geq 150 \mathrm{mg} / \mathrm{dl}$; high-density lipoprotein $<40$ or 50 ; systolic BP $\geq 130$ or diastolic BP $\geq 85 \mathrm{mmHg}$; FPG $\geq 100 \mathrm{mg} / \mathrm{dl}(5.6 \mathrm{mmol} / \mathrm{l})$ or type 2 diabetes mellitus. 

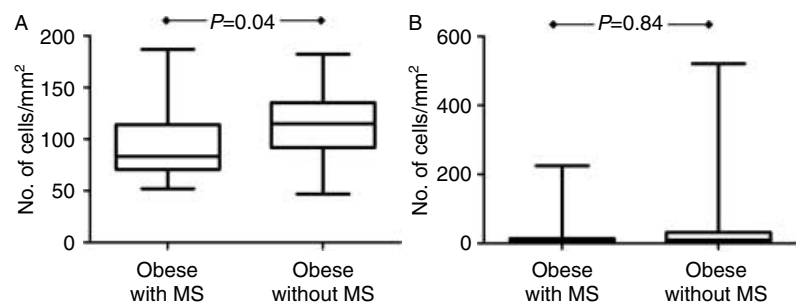

Figure 1 Ghrelin cell densities in oxyntic mucosa $(A)$ and in antral mucosa (B) of morbidly obese patients (BMI $>40$ ) with and withou metabolic syndrome (MS).

The $\chi^{2}$ and Fisher tests were used for categorical comparisons and the Student's $t$-test was used to compare means among groups. The Kruskal-Wallis or Mann-Whitney $U$ test was used to compare continuous versus categorical variables. A $P$ value $<0.05$ was considered to be statistically significant.

\section{Results}

The frequency of chronic gastritis and the prevalence of $H$. pylori infection were similar in morbidly obese patients and in non-obese dyspeptic patients. In addition, mild atrophy of the gastric mucosa was observed in only four $(8 \%)$ obese patients, in one $(5.8 \%)$ overweight patient, and in seven $(21.2 \%)$ lean patients (Table 1 ).

Ghrelin-immunoreactive cell density was lower in the oxyntic mucosa of morbidly obese patients with MS than in morbidly obese patients without this comorbidity $(P=0.04)$. In the antral mucosa, the density of ghrelin-immunoreactive cells was similar in both morbidly obese patient groups $(P=0.84$; Fig. 1$)$.

Ghrelin-immunoreactive cell density in the oxyntic mucosa was similar in morbidly obese patients with diabetes mellitus type 2 or MS and in overweight and lean patients. However, the density of ghrelin cells was higher in the oxyntic mucosa of morbidly obese patients without diabetes mellitus type 2 or MS compared with the two groups of non-obese patients. In the antral mucosa, the density of ghrelin-immunoreactive cells was higher in morbidly obese patients with or without diabetes type 2 or MS compared with the groups of overweight and lean subjects (Fig. 2).

The density of ghrelin-immunoreactive cells was higher in the oxyntic mucosa of $H$. pylori-negative patients than in H. pylori-positive patients of both the morbidly obese and the non-obese groups (Table 2). In the antral mucosa of lean patients, the density of ghrelin-immunoreactive cells was higher in H. pylorinegative subjects, whereas in the obese and overweight groups, there were no differences between H. pylorinegative and $H$. pylori-positive patients (Table 3 ).

As expected, almost all ghrelin-immunoreactive cells were seen in the oxyntic mucosa, whereas they were very few and scattered in the antral mucosa. Few small foci of immunoreactive cells were observed in the antral mucosa of ten $(20 \%)$ morbidly obese patients and in just one $(5.8 \%)$ overweight patient, and no such small groups of cells were observed in lean patients.

\section{Discussion}

The 28 amino acid peptide ghrelin was identified by Kojima et al. (1) and soon found to be present in highest concentrations in tissues in the oxyntic gastric mucosa $(2,3,30)$. In this region, the ghrelin-producing cells are located throughout the entire thickness of the mucosa and correlate topographically with the parietal cells (31).

The association between ghrelin and obesity started to emerge from experimental studies that showed an increase in appetite and adiposity after the administration of this peptide (32-34). In healthy subjects, the serum levels of ghrelin were demonstrated to be increased during periods of fasting and decreased after feeding, whereas in obese patients, the serum ghrelin levels usually did not present this behavior (21). Obese patients with Prader-Willi syndrome present increased plasma ghrelin concentrations and also have an increased density of ghrelin-producing cells in the gastric mucosa (23-26). Plasma ghrelin levels in children with Prader-Willi syndrome are elevated at any age, including during the first years of life and seem to precede the development of obesity (35). Thus, results of studies on the endocrine cell distribution in the gastric mucosa of obese patients may contribute to a better understanding of the role of this hormone regarding the mechanisms involved in the physiopathology of obesity.
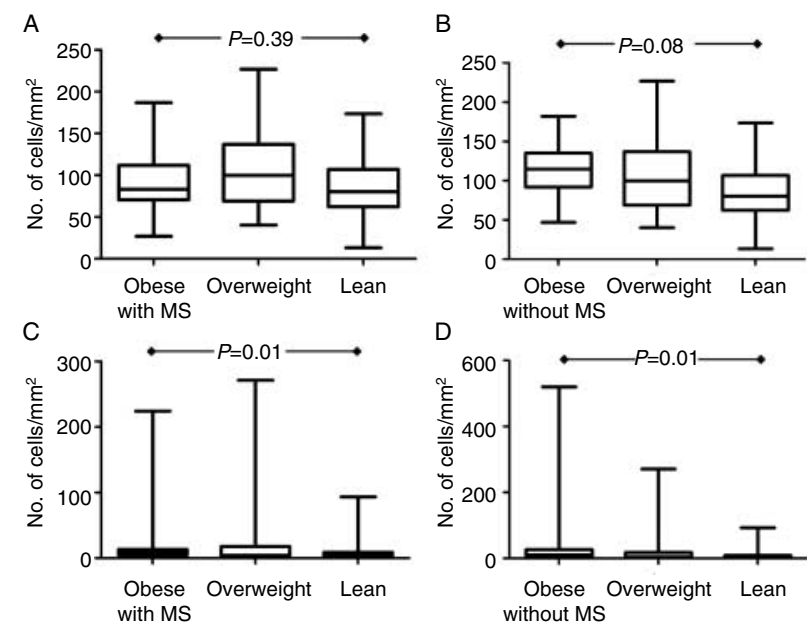

Figure 2 Ghrelin cell densities in oxyntic (A and B) and antral mucosa ( $C$ and $D)$ of morbidly obese patients (BMI $>40)$ with ( $A$ and $C)$ and without (B and $D$ ) metabolic syndrome (MS), overweight $(25<\mathrm{BMI}<30)$, and lean patients $(\mathrm{BMI}<25)$. 
Table 2 Mean density of ghrelin-producing cells (cells $/ \mathrm{mm}^{2}$ ) in oxyntic mucosa and H. pylori infection in morbidly obese (BMI $>40)$, overweight $(25<\mathrm{BMI}<30)$, and lean patients $(\mathrm{BMI}<25)$.

\begin{tabular}{|c|c|c|c|c|c|c|}
\hline \multirow{2}{*}{$\begin{array}{l}\text { H. pylori } \\
\text { infection }\end{array}$} & \multicolumn{2}{|r|}{ Obese } & \multicolumn{2}{|c|}{ Overweight } & \multicolumn{2}{|r|}{ Lean } \\
\hline & $n$ & Density & $n$ & Density & $n$ & Density \\
\hline Positive & 25 & $87.1 \pm 30.1^{*}$ & 8 & $71.8 \pm 27.8^{\dagger}$ & 22 & $70.74 \pm 37.3^{\ddagger}$ \\
\hline Negative & 25 & $108.5 \pm 34.2^{*}$ & 9 & $141.8 \pm 50.8^{\dagger}$ & 11 & $96.70 \pm 27.2^{\ddagger}$ \\
\hline Total & 50 & & 17 & & 33 & \\
\hline
\end{tabular}

${ }^{*} P=0.026,{ }^{\dagger} P=0.0005,{ }^{\ddagger} P=0.0001$.

McLaughlin et al. (17) reported that mean plasma ghrelin concentration was lower in obese insulin-resistant than in obese insulin-sensitive patients. Recently, Tong et al. (18) found that ghrelin infusion did not alter fasting insulin or glucose concentration but significantly decreased the acute insulin response to i.v. glucose, and a similar suppression of C-peptide was observed. This study has shown that the distribution and density of ghrelin-producing cells in the oxyntic mucosa appears to be higher in morbidly obese patients without MS than in morbidly obese patients with this insulin resistance-associated condition, and also higher compared with two groups of dyspeptic non-obese patients, i.e. overweight and lean patients. The difference between density of ghrelinproducing cells between morbidly obese patients with and without MS may indicate that some factor in obese patients with MS would be related to activity of the ghrelin-producing cells, also reducing its expression. This finding certainly deserves further investigation.

It has been shown that plasma ghrelin levels are lower in obese than in non-obese patients $(19,20)$. As expected, this apparently low secretion of ghrelin could be due to a decreased number of gastric endocrine cells, a fact that did not seem to occur in the morbidly obese subjects studied here. The results obtained in the various studies are apparently conflicting. However, the fact that a larger number of ghrelin-immunoreactive cells were detected in obese patients does not necessarily mean that the number of these cells was increasing. Among other possibilities, ghrelinproducing endocrine cells may accumulate more peptide due to some interference with the mechanisms of secretion, becoming hypertropic in obese patients and thus being more easily detected by immunohistochemical analysis. We have previously demonstrated that hypertropic neurons of the intramural plexuses of the intestine, when examined in histological sections, may simulate an increase in their numbers (36). Therefore, other factors could be responsible for the lower levels of serum ghrelin observed in obese patients, such as the presence of $H$. pylori infection, the most frequent worldwide pathogen affecting the gastric mucosa $(7-10)$. Several gastric hormones have been reported to be affected by this microorganism, such as gastrin and somatostatin (4-6). Would ghrelin-producing cells also be affected by this infection? Interestingly, it has been reported that an increase in body weight was noted after eradication of this microorganism and that H. pylori-positive children had a higher incidence of growth retardation $(37,38)$. Furthermore, morbid obesity and $H$. pylori infection seem to have an inverse relationship, leading to the hypothesis that the absence of $H$. pylori infection during childhood may enhance the risk of developing morbid obesity (39). Nwokolo et al. (9) reported increased plasma concentrations of ghrelin after eradication of $H$. pylori in lean, asymptomatic individuals. It has been reported that the number of ghrelin-producing cells is significantly lower in patients with $H$. pylori infection than in subjects without H. pylori infection, and the same difference was observed in the plasma concentrations of this peptide $(7,8,10$, $11,13)$. The results of this study are consistent with these findings. Therefore, $H$. pylori infection may affect the number of ghrelin-producing cells in the oxyntic mucosa. It is not known whether this may be the consequence of a direct influence of the microorganism or of factors related to the inflammatory reaction triggered by it. Gastric mucosa atrophy could explain a smaller number of a specific cell type in the gastric mucosa of $H$. pylori-infected patients. However, gastric mucosa atrophy was rarely observed in the present patient study. In addition, patients with atropic body gastritis suggestive of autoimmune etiology were excluded from this study. Despite the rarity of ghrelin cells in antral mucosa, the presence of scattered foci of these cells in this region seems to be responsible for the wide dispersion of these cell counts, as shown in Figs 1B, $2 \mathrm{C}$ and D. Could these small foci of ghrelin cells play some role in obesity? It may be hypothesized that ghrelin could activate the hypothalamic hunger center via the afferent vagus nerve, independent of plasma ghrelin levels. The detection of ghrelin receptors on

Table 3 Mean density of ghrelin-producing cells (cells $/ \mathrm{mm}^{2}$ ) in antral mucosa and $H$. pylori infection in morbidly obese $(\mathrm{BMI}>40)$, overweight $(25<\mathrm{BMI}<30)$, and lean patients $(\mathrm{BMI}<25)$.

\begin{tabular}{|c|c|c|c|c|c|c|c|c|c|}
\hline \multirow{2}{*}{$\begin{array}{l}\text { H. pylori } \\
\text { infection }\end{array}$} & \multicolumn{3}{|c|}{ Obese } & \multicolumn{3}{|c|}{ Overweight } & \multicolumn{3}{|c|}{ Lean } \\
\hline & $n$ & Mean & Median & $n$ & Mean & Median & $n$ & Mean & Median \\
\hline Positive & 25 & $50.9 \pm 93.5$ & $9.8^{*}$ & 8 & $4.5 \pm 9.21$ & $0.00^{\dagger}$ & 22 & $7.5 \pm 20.9$ & $0.0^{\ddagger}$ \\
\hline Negative & 25 & $39.4 \pm 108.9$ & $7.8^{*}$ & 9 & $43.3 \pm 93.0$ & $6.66^{\dagger}$ & 11 & $11.9 \pm 18.1$ & $4.4^{\ddagger}$ \\
\hline Total & 50 & & & 17 & & & 33 & & \\
\hline
\end{tabular}

${ }^{*} P=0.37,{ }^{\dagger} P=0.10,{ }^{\ddagger} P=0.04$. 
vagal afferent neurons in the rat nodose ganglion suggests that ghrelin signals from the stomach are transmitted to the brain via the vagus nerve and not only via the plasma levels that cross the blood-brain barrier (40). Some studies have shown that vagotomy inhibits the ability of ghrelin to stimulate food intake and $\mathrm{GH}$ release $(41,42)$.

In conclusion, the finding of a higher density of ghrelin-immunoreactive cells in the oxyntic mucosa of morbidly obese patients without diabetes mellitus type 2 or MS compared to lean subjects and also the finding of a higher number of small foci of ghrelin cells in the antral mucosa of obese patients may indicate an adaptive mechanism or an individual factor to be considered in the pathogenesis of obesity. We think that the present data could provide novel insights for understanding the role of gastric ghrelin and its relationship to obesity and insulin resistance.

\section{Declaration of interest}

The authors declare that there is no conflict of interest that could be perceived as prejudicing the impartiality of the research reported.

\section{Funding}

This study received financial support from Conselho Nacional de Desenvolvimento Científico e Tecnológico (CNPq), Brazil.

\section{Acknowledgements}

The authors thank Dr Eugenio M A Goulard for assistance with the statistical analysis and Ms Luciene S P Faria for technical assistance.

\section{References}

1 Kojima M, Hosoda H, Date $\mathrm{Y}$, Nakazato M, Matsuo H \& Kangawa K. Ghrelin is a growth-hormone-releasing acylated peptide from stomach. Nature 1999402 656-660. (doi:10.1038/ 45230)

2 Ariyasu H, Takaya K, Tagami T, Ogawa Y, Hosoda K, Akamizu T, Suda M, Koh T, Natsui K, Toyooka S, Shirakami G, Usui T, Shimatsu A, Doi K, Hosoda H, Kojima M, Kangawa K \& Nakao K. Stomach is a major source of circulating ghrelin, and feeding state determines plasma ghrelin-like immunoreactivity levels in humans. Journal of Clinical Endocrinology and Metabolism 200186 4753-4758. (doi:10.1210/jc.86.10.4753)

3 Date Y, Kojima M, Hosoda H, Sawaguchi A, Mondal MS, Suganuma T, Matsukura S, Kangawa K \& Nakazato M. Ghrelin, a novel growth hormone releasing acylated peptide, is synthesized in a distinct endocrine cell type in the gastro-intestinal tracts of rats and humans. Endocrinology 2000141 4255-4261. (doi:10. 1210/en.141.11.4255)

4 Marshall BJ \& Warren JR. Unidentified curved bacilli in the stomach of patients with gastritis and peptic ulceration. Lancet 19841 1311-1315. (doi:10.1016/S0140-6736(84)91816-6)

5 Queiroz DMM, Mendes N, Rocha GA, Moura SB, Resende LMH, Barbosa AJA, Coelho LGV, Passos MCE, Castro LP, Oliveira CA \& Lima GF. Effect of Helicobacter pylori eradication on antral gastrin-and-somatostatin immunoreactive cell density and gastrin and somatostatin concentrations. Scandinavian Journal of Gastroenterology 199328 858-864. (doi:10.3109/003655293 09103125)
6 Haruma K, Sumii K \& Okamoto S. Helicobacter pylori infection is associated with low antral somatostatin content in young adults. Implications for the pathogenesis of hypergastrinaemia. Scandinavian Journal of Gastroenterology 199530 550-553. (doi:10.3109/ 00365529509089788)

7 Osawa H, Nakazato M, Date Y, Kita H, Ohnishi H, Ueno H, Shiiya T, Satoh K. Ishino Y \& Sugano K. Impaired production of gastric ghrelin in chronic gastritis associated with Helicobacter pylori. Journal of Clinical Endocrinology and Metabolism 200590 10-16. (doi:10.1210/jc.2004-1330)

8 Osawa H. Ghrelin and Helicobacter pylori infection. World Journal of Gastroenterology 2008 14 6327-6333. (doi:10.3748/wjg.14.6327)

9 Nwokolo CU, Freshwater DA, O'Hare P \& Randeva HS. Plasma ghrelin following cure of Helicobacter pylori. Gut 2003 52 637-640. (doi:10.1136/gut.52.5.637)

10 Isomoto H, Ueno H, Saenko VA, Mondal MS, Nishi Y, Kawano N, Ohnita K, Mizuta Y, Ohtsuru A, Yamashita S, Nakazato M \& Kohno S. Impact of Helicobacter pylori infection on gastric and plasma ghrelin dynamics in humans. American Journal of Gastroenterology 2005100 1711-1720. (doi:10.1111/j.15720241.2005.41492.x)

11 Isomoto H, Ueno H, Nishi Y, Wen CY, Nakazato M \& Kohno S. Impact of Helicobacter pylori infection on ghrelin and various neuroendocrine hormones in plasma. World Journal of Gastroenterology 200511 1644-1648.

12 Gokcel A, Gumurdulu Y, Kayaselcuk F, Serin E, Ozer B, Ozsahin AK \& Guvener N. Helicobacter pylori has no effect on plasma ghrelin levels. European Journal of Endocrinology 2003148 423-426. (doi:10.1530/eje.0.1480423)

13 Liew PL, Lee WJ, Lee YC \& Chen WY. Gastric ghrelin expression associated with Helicobacter pylori infection and chronic gastritis in obese patients. Obesity Surgery 20066 612-619. (doi:10.1381/ 096089206776945002)

14 Saad MF, Bernaba B, Hwu CM, Jinagouda S, Fahmi S, Kogosov E \& Boyadjian R. Insulin regulates plasma ghrelin concentration. Journal of Clinical Endocrinology and Metabolism 200287 3997-4000. (doi:10.1210/jc.87.8.3997)

15 Ukkola O, Pöykkö SM \& Kesäniemi YA. Low plasma ghrelin concentration is an indicator of the metabolic syndrome. Annals of Medicine 200638 274-279. (doi:10.1080/0785389060062 2192)

16 Damjanovic SS, Lalic NM, Pesko PM, Petakov MS, Jotic A, Miljic D, Lalic KS, Lukic L, Djurovic M \& Djukic VB. Acute effects of ghrelin on insulin secretion and glucose disposal rate in gastrectomized patients. Journal of Clinical Endocrinology and Metabolism 200691 2574-2581. (doi:10.1210/jc.2005-1482)

17 McLaughlin T, Abbasi F, Lamendola C, Frayo RS \& Cummings DE. Plasma ghrelin concentrations are decreased in insulin resistant obese adults relative to equally obese insulin sensitive controls. Journal of Clinical Endocrinology and Metabolism 2004 89 1630-1635. (doi:10.1210/jc.2003-031572)

18 Tong J, Prigeon RL, Davis HW, Bidlingmaier M, Kahn SE, Cummings DE, Tschöp MH \& D'Alessio D. Ghrelin suppresses glucose-stimulated insulin secretion and deteriorates glucose tolerance in healthy humans. Diabetes 201059 2145-2151. (doi:10.2337/db10-0504)

19 Tschop M, Weyer C, Tataranni PA, Devanarayan V, Ravussin E \& Heiman ML. Circulating ghrelin levels are decreased in human obesity. Diabetes 200150 707-709. (doi:10.2337/diabetes.50.4. 707)

20 Hansen TK, Dall R, Hosoda H, Kojima M, Kangawa K, Christiansen JS \& Ljørgensen JOL. Weight loss increases circulating levels of ghrelin in human obesity. Clinical Endocrinology 200256 203-206. (doi:10.1046/j.0300-0664. 2001.01456.x)

21 English PJ, Ghatei MA, Malik IA, Bloom SR \& Wilding JP. Food fails to suppress ghrelin levels in obese humans. Journal of Clinical Endocrinology and Metabolism 200287 2984-2987. (doi:10. $1210 /$ jc. 87.6.2984)

22 Shiiya T, Nakazato M, Mizuta M, Date Y, Mondal MS, Tanaka M, Nozoe S, Hosoda H, Kangawa K \& Matsukura S. Plasma ghrelin 
levels in lean and obese humans and the effect of glucose on ghrelin secretion. Journal of Clinical Endocrinology and Metabolism 200287 240-244. (doi:10.1210/jc.87.1.240)

23 Cummings DE, Clement K, Purnell JQ, Vaisse C, Foster KE, Frayo RS, Schwartz MW, Basdevant A \& Weigle DS. Elevated plasma ghrelin levels in Prader-Willi syndrome. Nature Medicine 20028 643-664. (doi:10.1038/nm0702-643)

24 Delparigi A, Tschop M, Heiman ML, Salbe AD, Vozarova B, Sell SM, Bunt JC \& Tataranni PA. High circulating ghrelin: a potential cause for hyperphagia and obesity in Prader-Willi syndrome. Journal of Clinical Endocrinology and Metabolism $2002 \mathbf{8 7}$ 5461-5464. (doi:10.1210/jc.2002-020871)

25 Haqq AM, Farooqi IS, O'Rahilly S, Stadler DD, Rosenfeld RG, Pratt KL, LaFranchi SH \& Purnell JQ. Serum ghrelin levels are inversely correlated with body mass index, age, and insulin concentrations in normal children and are markedly increased in Prader-Willi syndrome. Journal of Clinical Endocrinology and Metabolism 200388 174-178. (doi:10.1210/jc.2002-021052)

26 Choe YH, Song SY, Paik LH, Oh YJ, Chu SH, Yeo SH, Kwon EK, Kim EM, Rha MY \& Jin DK. Increased density of ghrelin expressing cells in the gastric fundus and body in Prader-Willi syndrome. Journal of Clinical Endocrinology and Metabolism 2005 90 5441-5445. (doi:10.1210/jc.2004-1935)

27 Alberti KG, Zimmet P \& Shaw J. The metabolic syndrome - a new worldwide definition. Lancet 2005366 1059-1062. (doi:10. 1016/S0140-6736(05)67402-8)

28 Expert Panel on Detection, Evaluation, and Treatment of High Blood Cholesterol in Adults. Executive summary of the third report of the National Cholesterol Education Program (NCEP) expert panel on detection, evaluation, and treatment of high blood cholesterol in adults (Adult Treatment Panel III). Journal of the American Medical Association 2001285 2486-2497. (doi:10. 1001/jama.285.19.2486)

29 Dixon MF, Genta RM, Yardley JH \& Correa P. Classification and grading of gastritis. The Updated Sydney System. International Workshop on the Histopathology of Gastritis, Houston. American Journal of Surgical Pathology 199420 1161-1181. (doi:10.1097/ 00000478-199610000-00001)

30 Rindi G, Necchi V, Savio A, Torsello A, Zoli M, Locatelli V, Raimondo F, Cocchi D \& Solcia E. Characterization of gastric ghrelin cells in man and other mammals: studies in adult and fetal tissues. Histochemistry and Cell Biology 2002117 511-551. (doi:10.1007/s00418-002-0415-1)

31 Tanaka-Shintani M \& Watanabe M. Distribution of ghrelinimmunoreactive cells in human gastric mucosa: comparison with that of parietal cells. Journal of Gastroenterology $2005 \mathbf{4 0}$ 345-349. (doi:10.1007/s00535-004-1550-3)

32 Tschop M, Smiley DL \& Heiman ML. Ghrelin induces adiposity in rodents. Nature 2000407 908-913. (doi:10.1038/35038090)
33 Wren AM, Seal LJ, Cohen MA, Brynes AE, Frost GS, Murphy KG, Dhillo WS, Ghatei MA \& Bloom SR. Ghrelin enhances appetite and increases food intake in humans. Journal of Clinical Endocrinology and Metabolism 200186 5992. (doi:10.1210/jc.86.12.5992)

34 Cummings DE, Purnell JQ, Frayo RS, Schmidova K, Wisse BE \& Weigle DS. A preprandial rise in plasma ghrelin levels suggests a role in meal initiation in humans. Diabetes 200150 1714-1719. (doi:10.2337/diabetes.50.8.1714)

35 Feigerlová E, Diene G, Conte-Auriol F, Molinas C, Gennero I, Salles JP, Arnaud C \& Tauber M. Hyperghrelinemia precedes obesity in Prader-Willi syndrome. Journal of Clinical Endocrinology and Metabolism 200893 2800-2805. (doi:10.1210/jc.2007-2138)

36 Barbosa AJA \& Tafuri WL. Ganglion cell number in hypertrophic colon above experimental stenois. Brazilian Journal of Medical and Biological Research 198316 165-169.

37 Richter T, List S, Müller DM, Deutscher J, Uhlig HH, Krumbiegel P, Herbarth O, Gutsmuths FJ \& Kiess W. Five- to 7-year-old children with Helicobacter pylori infection are smaller than Helicobacternegative children: a cross-sectional population-based study of 3,315 children. Journal of Pediatric Gastroenterology and Nutrition 200133 472-475. (doi:10.1097/00005176-200110000-00010)

38 Abdullahi M, Annibale B, Capoccia D, Tari R, Lahner E, Osborn J, Leonetti F \& Severi C. The eradication of Helicobacter pylori is affected by body mass index. Obesity Surgery 200818 1450-1454. (doi:10.1007/s11695-008-9477-z)

39 Wu MS, Lee WJ, Wang HH, Huang SP \& Lin JT. A case control study of association of Helicobacter pylori infection with morbid obesity in Taiwan. Archives of Internal Medicine 2005165 1552-1555. (doi:10.1001/archinte.165.13.1552)

40 Wren AM, Small CJ, Fribbens CV, Neary NM, Ward HL, Seal LJ, Ghatei MA \& Bloom SR. The hypothalamic mechanisms of the hypophysiotropic action of ghrelin. Neuroendocrinology 200276 316-324. (doi:10.1159/000066629)

41 Burdyga G, Varro A, Dimaline R, Thompson DG \& Dockray GJ. Ghrelin receptors in rat and human nodose ganglia: putative role in regulating $\mathrm{CB}-1$ and $\mathrm{MCH}$ receptor abundance. American Journal of Physiology. Gastrointestinal and Liver Physiology 2006 290 G1289-G1297. (doi:10.1152/ajpgi.00543.2005)

42 Le Roux CW, Neary NM, Halsey TJ, Small CJ, Martinez-Isla AM, Ghatei MA, Theodorou NA \& Bloom SR. Ghrelin does not stimulate food intake in patients with surgical procedures involving vagotomy. Journal of Clinical Endocrinology and Metabolism 2005 90 4521-4524. (doi:10.1210/jc.2004-2537)

Received 31 March 2011

Accepted 9 May 2011 